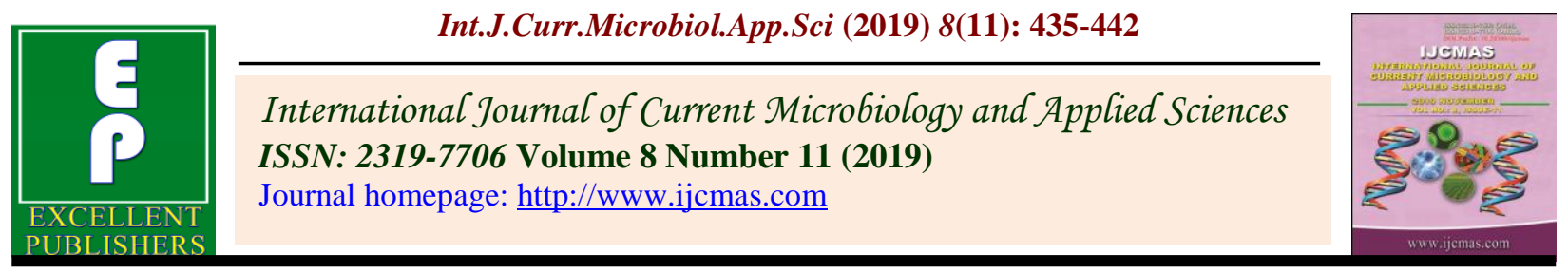

Original Research Article

https://doi.org/10.20546/ijcmas.2019.811.054

\title{
Preparation of GPS and GIS based Soil Maps on Fertility Status and Physico-Chemical Properties of Nayagarh District, Odisha, India
}

\author{
Tupaki Lokya", Antaryami Mishra, S. Saren and R.K. Nayak \\ Department of Soil Science and Agricultural chemistry, OUAT, Bhubaneswar, Odisha, India \\ *Corresponding author
}

\section{A B S T R A C T}

Keywords

GPS, GIS, Soil

fertility maps and

Fertility status

\section{Article Info}

Accepted:

07 October 2019

Available Online:

10 November 2019
The present investigation was carried out to study the available nutrient status and to prepare soil fertility maps which are important for nutrient management for higher and sustainable crop production. Five hundred two (502) numbers of soil samples were collected from different villages of all the eight blocks of Nayagarh District by using Global Positioning System (GPS) followed by analysis of physico-chemical properties and maps were prepared subsequently. The results revealed that the soils under investigation were acidic in reaction ( $\mathrm{pH} 5.74$ to 6.49$)$, low in EC $\left(0.08\right.$ to $\left.0.14 \mathrm{dS} \mathrm{m}^{-1}\right)$ and organic carbon status ( 5.5 to $6.8 \mathrm{~g} \mathrm{~kg}^{-1}$ ). The mean values of available nitrogen content varied from 124.8 to $186.2 \mathrm{~kg} \mathrm{ha}^{-1}$, available $\mathrm{P}$ from 6.3 to $13.78 \mathrm{~kg} \mathrm{ha}^{-1}$ and potassium status from 223.0 to $297.7 \mathrm{~kg} \mathrm{ha}^{-1}$. Thus, soils were found to be deficient in available $\mathrm{N}$ and $\mathrm{P}$ and medium in potassium status in Nayagarh district. The soil status of mean available Sulphur was high (14.98 to $24.22 \mathrm{mg} \mathrm{kg}^{-1}$ ) except in Daspalla block. Hot water soluble boron content was above the critical limit $\left(0.42\right.$ to $\left.0.60 \mathrm{mg} \mathrm{kg}^{-1}\right)$ in most of the soils of Nayagarh district. Mostly four types of texture classes were observed in the district namely loamy sand, sandy loam, clay loam and sandy clay loam. Clay content was found to be positively correlated with all the parameters. Significantly positive correlation among different parameters was found except sand which showed negative correlation with all the parameters.

\section{Introduction}

Nayagarh district with an area of $3890 \mathrm{Sq} \mathrm{Km}$ is bounded between latitudes $19^{0} 53^{\prime} 52^{\prime \prime} \mathrm{N}$ and $20^{\circ} 34^{\prime} 46^{\prime \prime} \mathrm{N}$ and longitudes $84^{\circ} 29^{\prime} 26^{\prime}$ " $\mathrm{E}$ and $85^{\circ} 27^{\prime} 22^{\prime \prime} \mathrm{E}$. The district is situated on the hilly ranges in the West and its North Eastern parts have formed small well cultivated fertile valleys intersected by small streams. It is bounded by Boudh district in the west, Cuttack and Angul district in the north, Khurda district in the east and Khurda and Ganjam district in the south. There are eight community development blocks in the district with its headquarter at Nayagarh town. The Nayagarh district has population of 962,789 of which male and female are 502,636 and 460,153 respectively(census of 2011).Efficient management of soil and water resources is a major challenge for the scientists, planners, 
administrators and farmers to ensure food, water and environmental security for the present and future generations (Kanwar, 2000). Soil fertility plays an important role in sustaining crop productivity of an area, particularly in situations where input of nutrients application differs and the information on the nutritional status can go a long way to develop economically viable alternatives for management of deficient nutrients in the soil.

The modern geospatial technologies such as Remote Sensing (RS), Geographical Information System (GIS), Global Positioning System (GPS) and Information Technology (IT) offer immense potential for soil and water resources development and management (Das 2004). The Global Positioning System (GPS), is a space-based satellite navigation system that provides location and time information in all weather conditions. The FAO Soil Map of the World (FAO 1996) is an important source of soil information used world-wide. Collection of soil samples by using Global Positioning System (GPS) is very important for preparing the GPS and GIS based thematic soil fertility maps (Mishra et al., 2013). Detail systematic study of the soil fertility status of Nayagarh district of Odisha has not been done. Therefore, the present investigation was carried out with an objective to study the soil fertility status in detail of Nayagarh district with GPS and GIS tools and to prepare the soil fertility maps for understanding easily about the soil fertility status of Nayagarh district.

\section{Materials and Methods}

A total of 502 surface soil sample were collected from different villages of all the eight blocks of Nayagarh district namely Odagaon (69), Nuagaon (64), Ranpur (73), Nayagarh (61), Khandapada (65), Gania (56), Daspalla (60) and Bhapur (54) by using Global Positioning System (GPS). The soil samples were analyzed for texture (Bouyoucos hydrometer), $\mathrm{pH}$ (1:2.5), EC (1:2.5), organic carbon (Walkley and Black method), available nitrogen (alkaline permanganate method), available phosphorus (Bray's No.-1), available potassium (neutral normal ammonium acetate method), available boron (hot water extraction) and available $\left(0.15 \% \quad \mathrm{CaCl}_{2}\right)$ Sulphur as per standard procedure (Jackson, 1973) and correlation of coefficient among the physio-chemical properties with mean values of each block of Nayagarh district was studied. Base map of Nayagarh district was digitized and geo-referenced. Polygons were superimposed on the geo-referred map. Then latitude, longitude and soil characteristics such as soil reaction, organic carbon, available nitrogen, available phosphorus, available potassium, and Available sulphur and hot water extractable boron contents were linked to Arc GIS software for making thematic soil fertility maps.

\section{Results and Discussion}

Majority of surface Soil texture of Nayagarh district are found to be sandy clay loam, clay loam, sandy loam and loamy sand (Table 1). The average sand content varied from $43 \%$ in Gania block to $78 \%$ in Odagaon and Nuagaon blocks, silt content from $08 \%$ in Odagaon to $25 \%$ Gania block and clay content varied from $14 \%$ in Odagaon block to $32 \%$ in Gania block. The block wise sand content was found to be in the range of Odagaon (68 to $88 \%$ ), Nuagaon (48 to $86 \%$ ), Ranpur (34 to $78 \%$ ), Nayagarh (50 to 90\%), Khandapada (46 to $84 \%$ ), Gania (22 to $78 \%$ ), Daspalla (44 to $82 \%$ ) and Bhapur (42 to 80\%). Whereas,Silt content Odagaon (04 to $14 \%$ ), Nuagaon (04 to $30 \%$ ), Ranpur (10 to $26 \%$ ), Nayagarh (04 to $30 \%$ ), Khandapada (06 to 30\%), Gania (10 to $42 \%$ ), Daspalla (10 to $44 \%$ ) and Bhapur (11 to $44 \%$ ). Odagaon (68 to $88 \%$ ), Nuagaon (48 to $86 \%$ ), Ranpur (34 to $78 \%$ ), Nayagarh (50 to $90 \%$ ), Khandapada (46 to $84 \%$ ), Gania (22 to 
$78 \%$ ), Daspalla (44 to 82\%) and Bhapur (42 to $80 \%$ ). The clay content were Odagaon (08 to $26 \%$ ), Nuagaon (10 to 30\%), Ranpur (12 to $46 \%$ ), Nayagarh (06 to 30\%), Khandapada (12 to $36 \%$ ), Gania (12 to $42 \%$ ), Daspalla (10 to $44 \%$ ) and Bhapur (11 to $44 \%$ ).

The average soil $\mathrm{pH}$ of the Nayagarh district ranged from 5.74 to 6.49 (moderately acidic to neutral). The soil $\mathrm{pH}$ of Odagaon block soil varied from 5.02 to 7.89 (moderately acidic to saline) with a mean value 5.91 (Fig. 1). Similarly, blocks namely Nuagaon, Ranpur, Nayagarh, Khandapada, Gania, Daspalla and Bhapur soils had $\mathrm{pH}$ value of 5.34 to 7.32 , 4.80 to $7.37,4.87$ to $7.10,4.53$ to $7.92,5.83$ to $7.93,4.98$ to 7.66 and 4.31 to 7.56 , respectively with their respective mean value of $6.29,6.20,5.74,5.95,6.49,6.22$ and 5.86. The investigation revealed that Bhapur and Khandapada soils were extremely acidic to neutral whereas, Ranpur, Nayagarh and Daspalla had very strong acidic to neutral in reaction and Odagaon, Nuagaon, and Gania had strong acidic to slightly saline in nature. The lowest electrical conductivity value was found in the soil of Nuagaon $\left(0.01 \mathrm{dSm}^{-1}\right)$ and Ranpur $\left(0.01 \mathrm{dSm}^{-1}\right)$ whereas, the highest value was found in Daspalla $\left(0.58 \mathrm{dSm}^{-1}\right)$, Ranpur $\left(0.56 \mathrm{dSm}^{-1}\right)$ and Khandapada (0.56 $\left.\mathrm{dSm}^{-1}\right)$. The mean value of all the blocks varied between 0.08 and $0.14 \mathrm{dSm}^{-1}$ which is very low and safe for crop cultivation.

The soil organic carbon (SOC) content of all the blocks varied between low $(<0.50 \%)$ to high $(>0.75 \%)$ and presented in Table 2 and Figure 2. The block wise SOC content was varied in Odagaon (1.2 to $\left.16.7 \mathrm{~g} \mathrm{~kg}^{-1}\right)$, Nuagaon (1.7 to $15.6 \mathrm{~g} \mathrm{~kg}^{-1}$ ), Ranpur (2.1 to $12.8 \mathrm{~g} \mathrm{~kg}^{-1}$ ), Nayagarh (1.7 to $10.5 \mathrm{~g} \mathrm{~kg}^{-1}$ ), Khandapada (2.3 to $12.5 \mathrm{~g} \mathrm{~kg}^{-1}$ ), Gania (3.1 to $10.5 \mathrm{~g} \mathrm{~kg}^{-1}$ ), Daspalla (2.1 to $13.5 \mathrm{~g} \mathrm{~kg}^{-1}$ ) and Bhapur (2.7 to $\left.12.6 \mathrm{~g} \mathrm{~kg}^{-1}\right)$ with their respective mean value was $5.5,5.8,6.8,6.6$, $6.3,6.7,6.5$ and $5.7 \mathrm{~g} \mathrm{~kg}^{-1}$. The highest $(16.7 \mathrm{~g}$ $\left.\mathrm{kg}^{-1}\right)$ and lowest $\left(1.2 \mathrm{~g} \mathrm{~kg}^{-1}\right)$ organic carbon content were observed in soils of Odogaon block. The highest mean value of organic carbon content (6.8 $\mathrm{g} \mathrm{kg}-1)$ was found in Ranpur block $\left(6.8 \mathrm{~g} \mathrm{~kg}^{-1}\right)$.

The soils were found to be low in available nitrogen content in all the blocks of Nayagarh district except Nayagarh (75.0 to $355.0 \mathrm{~kg}$ $\mathrm{ha}^{-1}$ ), Khandapada (87.5 to $325.0 \mathrm{~kg} \mathrm{ha}^{-1}$ ) and Ranpur (87.5 to $337.0 \mathrm{~kg} \mathrm{ha}^{-1}$ ) which ranged from low to medium (Fig. 3). The average available nitrogen content was low $(124.5 \mathrm{~kg}$ ha-1). The lowest available nitrogen content was observed in Daspalla block which ranged from 75.0 to $175.0 \mathrm{~kg} \mathrm{ha}^{-1}$ with a mean value of $124.8 \mathrm{~kg} \mathrm{ha}^{-1}$ and the highest in Nayagarh block which ranged from 75.0 to $355.0 \mathrm{~kg} \mathrm{~kg}$ $\mathrm{ha}^{-1}$ with a mean value of $186.2 \mathrm{~kg} \mathrm{ha}^{-1}$ was recorded. Similar results were also reported by Mitra et al., (2002). The available soil phosphorus content in all the blocks of Nayagarh district was observed between low $\left(<14 \mathrm{~kg} \mathrm{ha}^{-1}\right)$ to medium $\left(14-40 \mathrm{~kg} \mathrm{ha}^{-1}\right)$. The highest available soil phosphorus content was found in Daspalla block $\left(53.1 \mathrm{~kg} \mathrm{ha}^{-1}\right)$ and lowest in Ranpur blocks (1.2 kg ha-1) (Fig. 4). Similar result was reported by Mitra et al., (2002) and Mandal et al., (2013). Available soil Potassium content in all the blocks of the district ranged from low to high (Table 3 and Fig. 5). The lowest mean available soil potassium content was found in Daspalla block $\left(223 \mathrm{~kg} \mathrm{ha}^{-1}\right)$ which was in medium range and highest in Nayagarh $\left(297.7 \mathrm{~kg} \mathrm{ha}^{-1}\right)$ followed by Khandapada block (293.9 $\mathrm{kg} \mathrm{ha}^{-1}$ ) soils which were in high range. Similar results were reported by Mitra et al., (2006).

The status of available sulphur and hot water soluble boron content are presented in Table 4 and Figure 6. The highest available Sulphur was recorded in Ranpur block (85.12 $\mathrm{mg} \mathrm{kg}^{-1}$ ) and the lowest available $\mathrm{S}\left(1.25 \mathrm{mg} \mathrm{kg}^{-1}\right)$ status was observed in the soils of Khandapada block. 
Table.1 Range and mean values of sand, silt and clay content (\%) with textural class of different blocks of Nayagarh district

\begin{tabular}{|c|c|c|c|c|c|c|c|c|c|}
\hline $\begin{array}{c}\text { S. } \\
\text { No }\end{array}$ & Block name & $\begin{array}{c}\text { Number } \\
\text { of soil }\end{array}$ & \multicolumn{2}{|c|}{ Sand (\%) } & \multicolumn{2}{c|}{ Silt (\%) } & \multicolumn{2}{c|}{ Clay (\%) } & Textural class \\
\cline { 3 - 8 } & & samples & Range & Mean & Range & Mean & Range & Mean & \\
\hline $\mathbf{1}$ & Odagaon & 69 & $68-88$ & 78 & $04-14$ & 08 & $08-26$ & 14 & Loamy sand \\
\hline $\mathbf{2}$ & Nuagaon & 64 & $48-86$ & 78 & $04-30$ & 13 & $10-30$ & 19 & Sandy loam \\
\hline $\mathbf{3}$ & Ranpur & 73 & $34-78$ & 49 & $10-26$ & 21 & $12-46$ & 30 & Clay loam \\
\hline $\mathbf{4}$ & Nayagarh & 61 & $50-90$ & 72 & $04-30$ & 12 & $06-30$ & 16 & Sandy loam \\
\hline $\mathbf{5}$ & Khandapada & 65 & $46-84$ & 60 & $06-30$ & 18 & $12-36$ & 22 & Sandy clay loam \\
\hline $\mathbf{6}$ & Gania & 56 & $22-78$ & 43 & $10-26$ & 25 & $12-42$ & 32 & Clay loam \\
\hline $\mathbf{7}$ & Daspalla & 60 & $44-82$ & 66 & $08-14$ & 12 & $10-44$ & 22 & Sandy clay loam \\
\hline $\mathbf{8}$ & Bhapur & 54 & $42-80$ & 65 & $07-15$ & 11 & $11-44$ & 24 & Sandy clay loam \\
\hline
\end{tabular}

Table.2 Range and mean values of soil pH, EC and organic carbon indifferent blocks of Nayagarh district

\begin{tabular}{|c|c|c|c|c|c|c|c|c|}
\hline S.No & Block name & $\begin{array}{c}\text { No of } \\
\text { samples }\end{array}$ & \multicolumn{2}{|c|}{$\mathbf{p H}(\mathbf{1} \mathbf{2})$} & \multicolumn{2}{c|}{$\mathbf{E C}\left(\mathbf{d S m}^{-\mathbf{1}}\right)$} & \multicolumn{2}{c|}{$\left.\mathbf{O C} \mathbf{g ~ k g}^{-1}\right)$} \\
\hline $\mathbf{1}$ & Odagaon & 69 & $5.02-7.98$ & 5.91 & $0.04-0.39$ & 0.11 & $1.2-16.7$ & 5.5 \\
\hline $\mathbf{2}$ & Nuagaon & 64 & $5.34-7.32$ & 6.29 & $0.01-0.47$ & 0.08 & $1.7-15.6$ & 5.8 \\
\hline $\mathbf{3}$ & Ranpur & 73 & $4.80-7.37$ & 6.20 & $0.01-0.56$ & 0.14 & $2.1-12.8$ & 6.8 \\
\hline $\mathbf{4}$ & Nayagarh & 61 & $4.87-7.10$ & 5.74 & $0.05-0.47$ & 0.13 & $1.7-10.5$ & 6.6 \\
\hline $\mathbf{5}$ & Khandapada & 65 & $4.53-7.92$ & 5.95 & $0.03-0.56$ & 0.13 & $2.3-12.5$ & 6.3 \\
\hline $\mathbf{6}$ & Gania & 56 & $5.83-7.93$ & 6.49 & $0.02-0.41$ & 0.11 & $3.1-10.5$ & 6.7 \\
\hline $\mathbf{7}$ & Daspalla & 60 & $4.98-7.66$ & 6.22 & $0.05-0.58$ & 0.13 & $2.1-13.5$ & 6.5 \\
\hline $\mathbf{8}$ & Bhapur & 54 & $4.31-7.56$ & 5.86 & $0.05-0.44$ & 0.12 & $2.7-12.6$ & 5.7 \\
\hline
\end{tabular}

Table.3 Range and mean values of available nutrients of N, P,K in soils of different blocks of Nayagarh district

\begin{tabular}{|c|c|c|c|c|c|c|c|c|}
\hline \multirow[t]{2}{*}{ S. No } & \multirow[t]{2}{*}{ Block name } & \multirow[t]{2}{*}{$\begin{array}{c}\text { No of } \\
\text { samples }\end{array}$} & \multicolumn{2}{|c|}{$\begin{array}{l}\text { Avail. N } \\
\left(\mathrm{kg} \mathrm{ha}^{-1}\right)\end{array}$} & \multicolumn{2}{|c|}{$\begin{array}{l}\text { Avail. P } \\
\left(\mathrm{kg} \mathrm{ha}^{-1}\right)\end{array}$} & \multicolumn{2}{|c|}{$\begin{array}{l}\text { Avail. K } \\
\left(\mathrm{kg} \mathrm{ha}^{-1}\right)\end{array}$} \\
\hline & & & Range & Mean & Range & Mean & Range & Mean \\
\hline 1 & Odagaon & 69 & $87.5-212.5$ & 126.3 & $1.3-22$ & 9.37 & $101-598$ & 261.8 \\
\hline 2 & Nuagaon & 64 & $77.5-225.5$ & 144.5 & $1.3-25.7$ & 6.32 & $33.6-462$ & 272.8 \\
\hline 3 & Ranpur & 73 & $87.5-337$ & 157.8 & $1.2-29$ & 10.53 & $90-652$ & 259.9 \\
\hline 4 & Nayagarh & 61 & $75-355$ & 186.2 & $1.6-29.4$ & 9.64 & $123-621$ & 297.7 \\
\hline 5 & Khandapada & 65 & $87.5-325$ & 141.8 & 2.9-24 & 8.69 & $76-892$ & 293.9 \\
\hline 6 & Gania & 56 & $100-200$ & 136.2 & $2.1-25.5$ & 10.56 & $75-496$ & 225.0 \\
\hline 7 & Daspalla & 60 & $75-175$ & 124.8 & $1.5-53.1$ & 13.78 & $21-668$ & 223.0 \\
\hline 8 & Bhapur & 54 & $95-184.57$ & 135.0 & $7.35-27$ & 13.06 & $42-531$ & 239.7 \\
\hline
\end{tabular}


Table.4 Range and mean values of available sulphur and hot water soluble boron content in soils of different blocks of Nayagarh district

\begin{tabular}{|c|c|c|c|c|c|c|}
\hline S. No & Block name & \multirow{2}{*}{$\begin{array}{c}\text { No of } \\
\text { samples }\end{array}$} & \multicolumn{2}{|c|}{ Avail. S $\mathbf{( ~ m g ~ k g - 1})$} & \multicolumn{2}{c|}{ Avail. B( mg kg $\left.\mathbf{~ k g}^{-1}\right)$} \\
\hline $\mathbf{1}$ & & Range & Mean & \multicolumn{2}{|c|}{ Range } & Mean \\
\hline $\mathbf{2}$ & Odagaon & 69 & $8.25-31.45$ & 18.57 & $0.09-0.89$ & 0.42 \\
\hline $\mathbf{3}$ & Nuagaon & 64 & $3.26-46.25$ & 21.59 & $0.10-0.97$ & 0.54 \\
\hline $\mathbf{4}$ & Ranpur & 73 & $1.90-85.12$ & 24.22 & $0.12-1.18$ & 0.53 \\
\hline $\mathbf{5}$ & Nayagarh & 61 & $3.95-77.25$ & 22.68 & $0.27-1.10$ & 0.46 \\
\hline $\mathbf{6}$ & Khandapada & 65 & $1.25-66.95$ & 20.92 & $0.06-2.43$ & 0.60 \\
\hline $\mathbf{7}$ & Gania & 56 & $6.50-66.12$ & 22.76 & $0.26-1.12$ & 0.62 \\
\hline $\mathbf{8}$ & Daspalla & 60 & $2.20-37.45$ & 14.98 & $0.22-1.21$ & 0.54 \\
\hline
\end{tabular}

Table.5 Correlation coefficient among different soil physico- chemical properties of Nayagarh district

\begin{tabular}{|c|c|c|c|c|c|c|c|c|c|c|c|}
\hline & Sand & Silt & Clay & $\mathbf{p H}$ & $\mathbf{E C}$ & $\mathbf{O C}$ & $\mathbf{N}$ & $\mathbf{P}$ & $\mathbf{K}$ & $\mathbf{S}$ & $\mathbf{B}$ \\
\hline Sand & 1.00 & & & & & & & & & & \\
\hline Silt & $-0.92^{* *}$ & 1.00 & & & & & & & & & \\
\hline Clay & $-0.94^{* *}$ & $0.87^{* *}$ & 1.00 & & & & & & & & \\
\hline $\mathbf{p H}$ & -0.53 & $0.65^{*}$ & $0.66^{*}$ & 1.00 & & & & & & & \\
\hline $\mathbf{E C}$ & -0.43 & 0.18 & 0.25 & -0.35 & 1.00 & & & & & & \\
\hline $\mathbf{O C}$ & $-0.71^{*}$ & $0.72^{*}$ & $0.59^{*}$ & 0.35 & $0.58^{*}$ & 1.00 & & & & & \\
\hline $\mathbf{N}$ & -0.01 & 0.11 & 0.11 & 0.37 & 0.27 & 0.45 & 1.00 & & & & \\
\hline $\mathbf{P}$ & -0.31 & 0.06 & 0.32 & 0.05 & $0.58^{*}$ & 0.21 & -0.30 & 1.00 & & & \\
\hline $\mathbf{K}$ & 0.40 & 0.18 & 0.53 & $0.58^{*}$ & 0.04 & 0.06 & $0.66^{*}$ & $0.69 *$ & 1.00 & & \\
\hline $\mathbf{S}$ & -0.42 & $0.60^{*}$ & 0.38 & 0.11 & 0.00 & 0.38 & $0.67^{*}$ & -0.51 & 0.43 & 1.00 & \\
\hline $\mathbf{B}$ & $-0.68^{*}$ & $0.69^{*}$ & $0.76^{* *}$ & $0.54^{*}$ & -0.01 & 0.33 & -0.26 & 0.15 & -0.34 & 0.15 & 1.00 \\
\hline
\end{tabular}

(Significant at $* * 1 \%$ and $* 5 \%$ level)

Fig.1 GPS and GIS based soil pH map of Nayagarh district

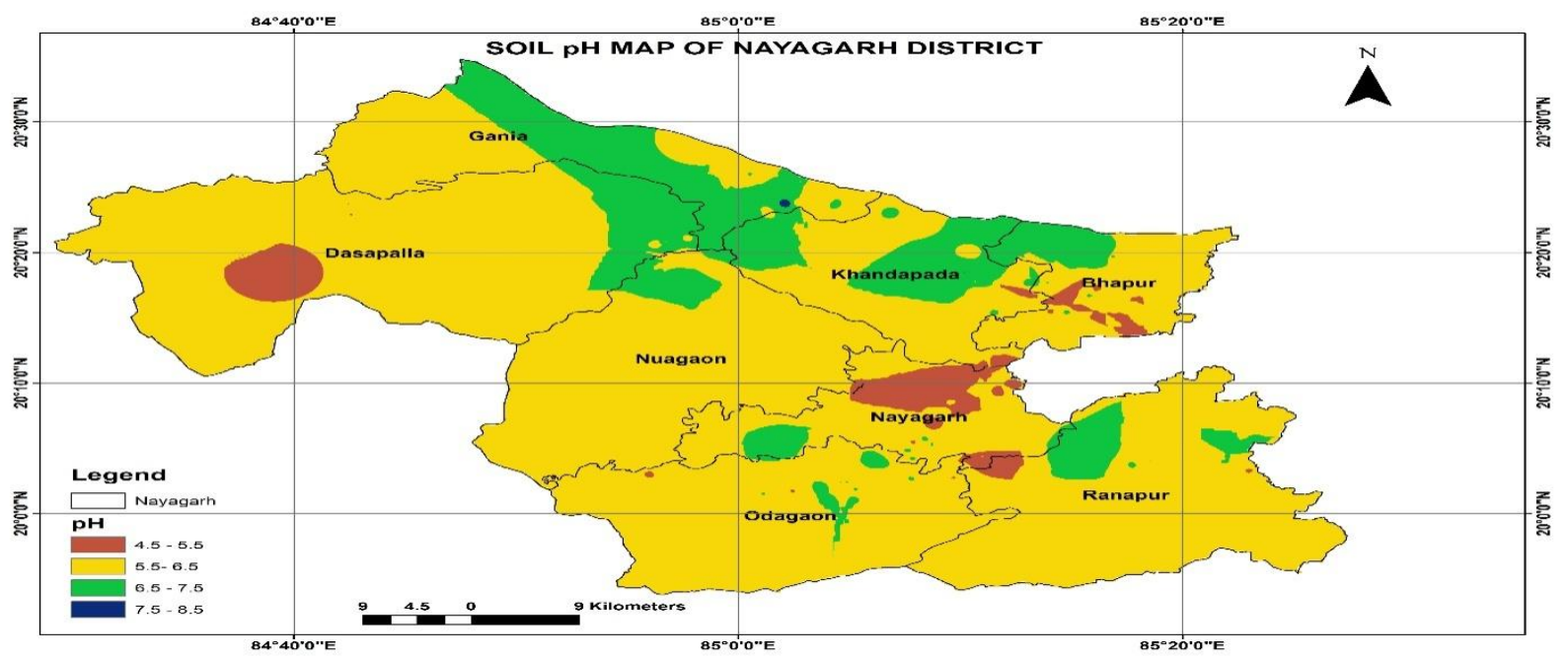


Fig.2 GPS and GIS based soil organic carbon map of Nayagarh district

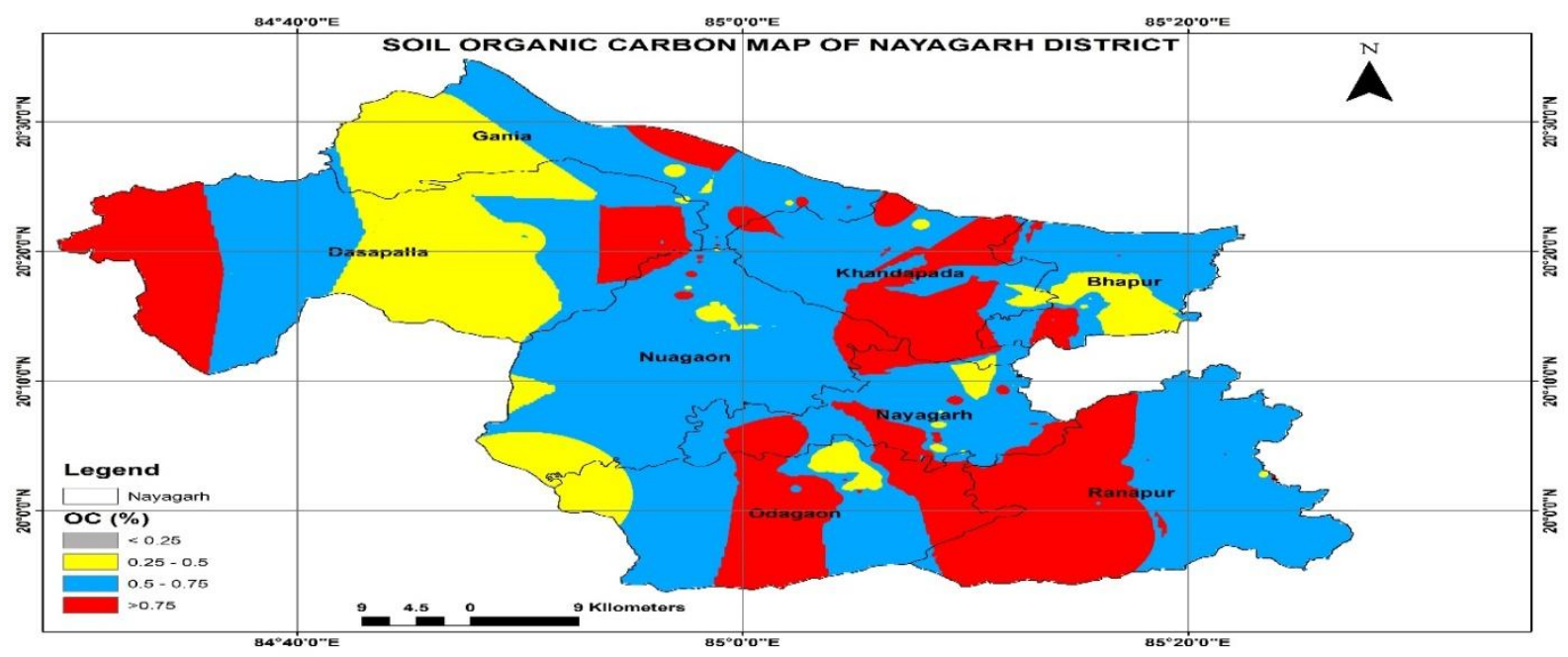

Fig.3 GPS and GIS based soil nitrogen map of Nayagarh district

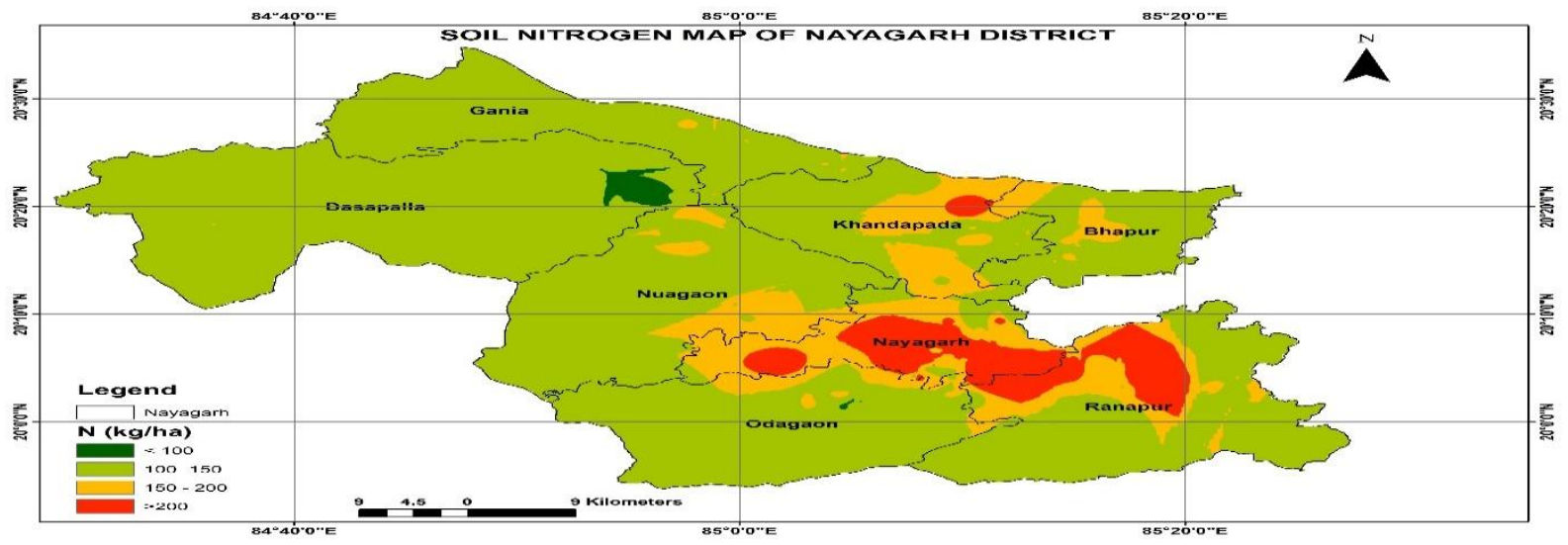

Fig.4 GPS and GIS based soil phosphorous map of Nayagarh district

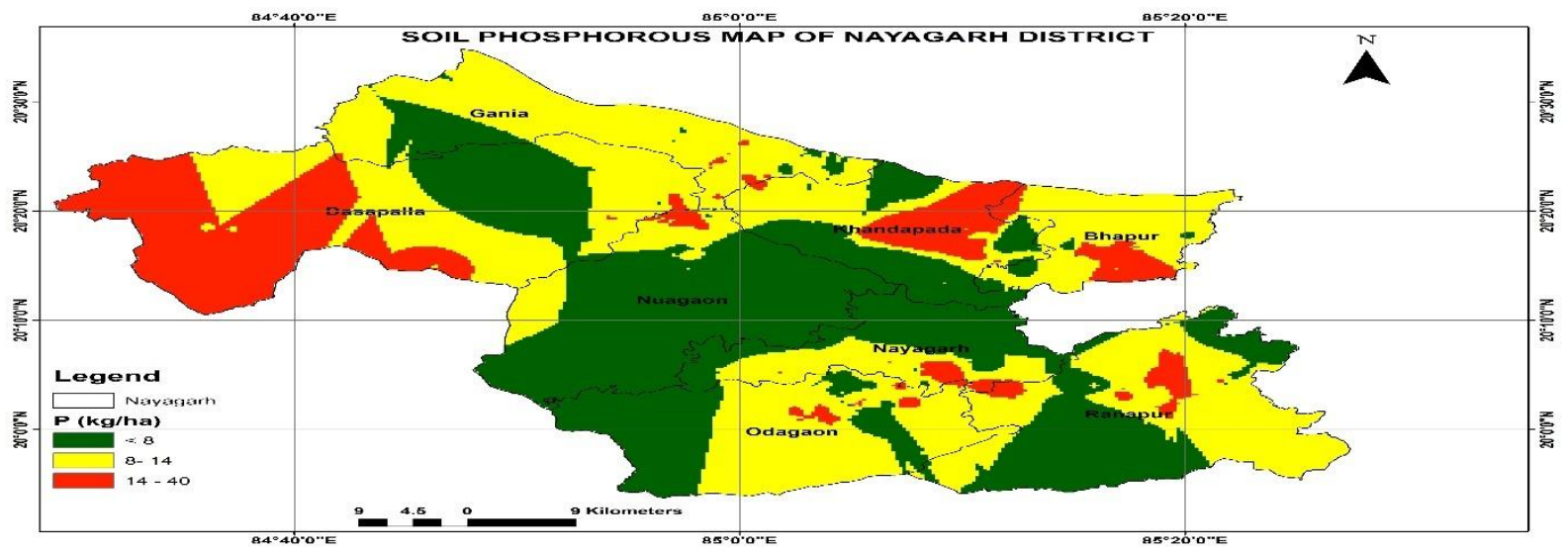


Fig.5 GPS and GIS based soil potassium map of Nayagarh district

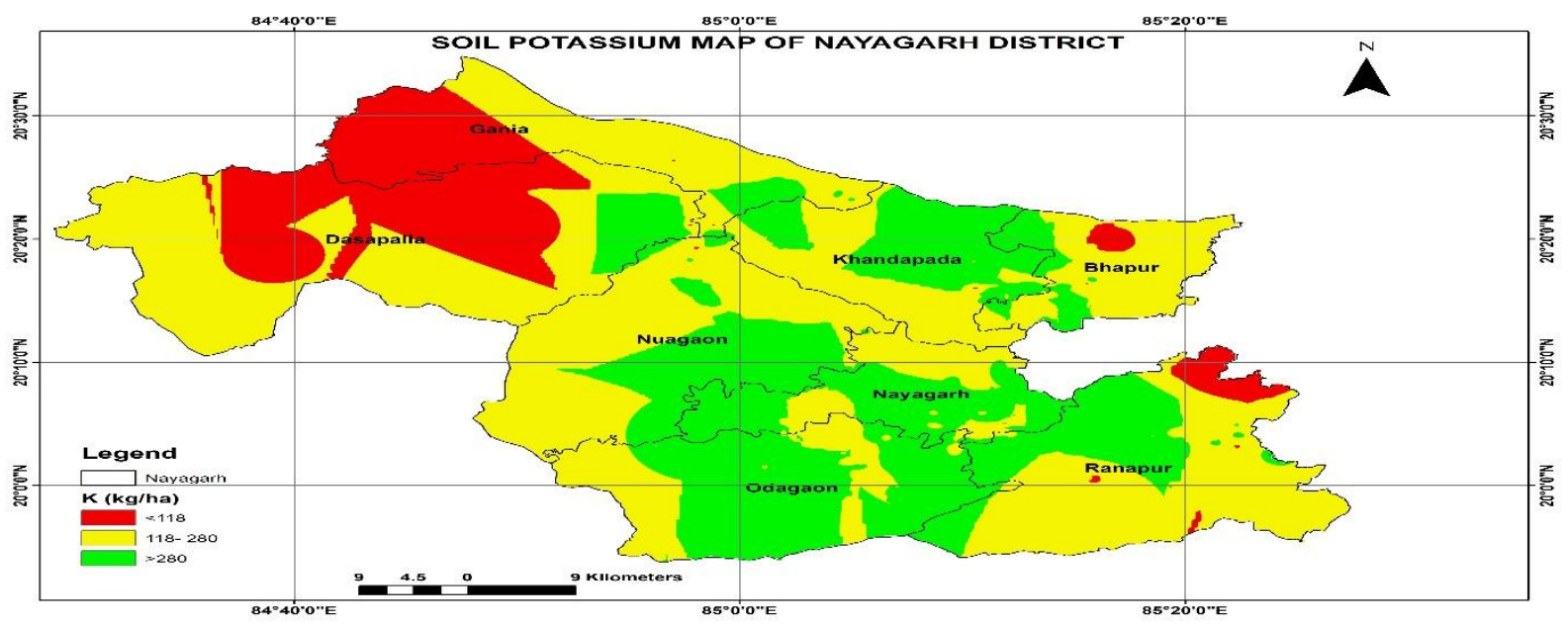

Fig.6 GPS and GIS based soil sulphur map of Nayagarh district

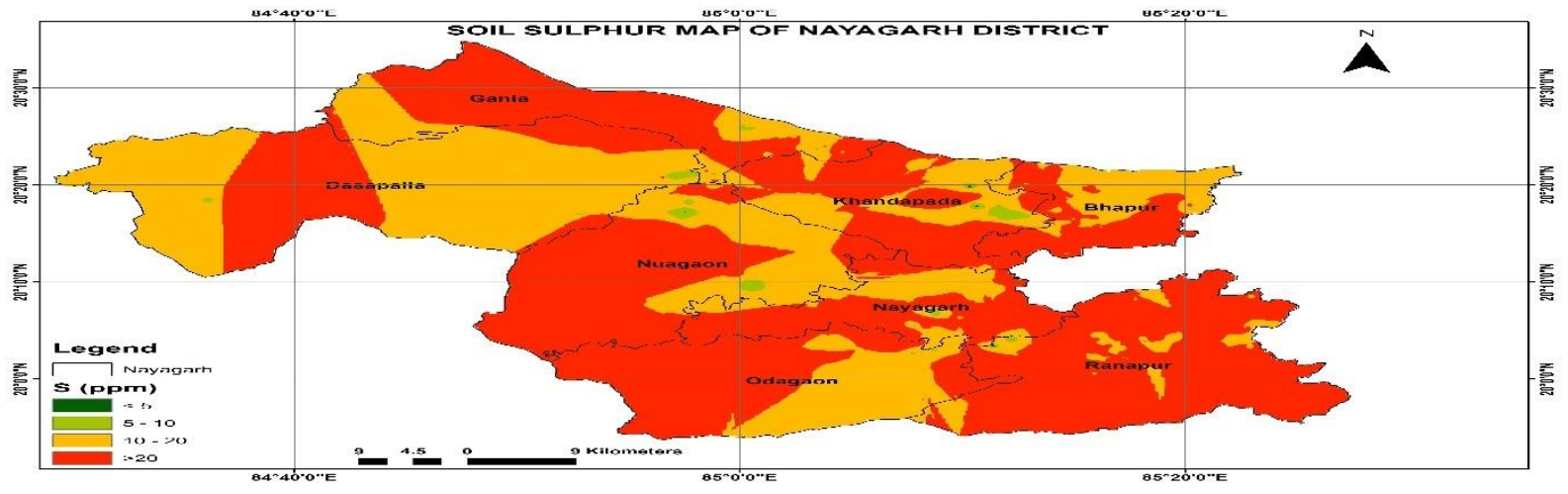

Fig.7 GPS and GIS based soil boron map of Nayagarh district

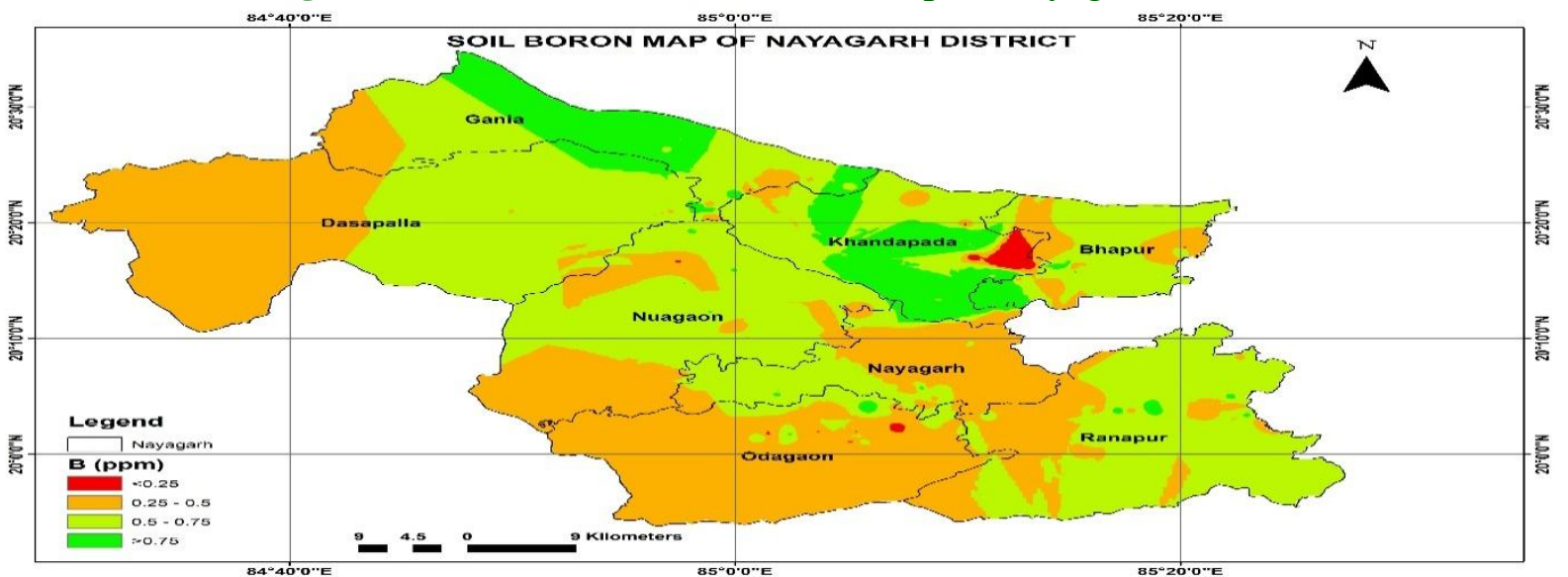

The mean available sulphur content in soils of different blocks of the district ranged from 14.98 to $24.22 \mathrm{mg} \mathrm{kg}^{-1}$. The mean value of hot water soluble boron content in all the blocks of the district was above the critical limit $\left(>0.5 \mathrm{mg} \mathrm{kg}^{-1}\right)$ expect Odagaon and Nayagarh 
block (Fig. 7). The highest mean value was observed in Khandapada block $\left(0.60 \mathrm{mg} \mathrm{kg}^{-1}\right)$ and lowest in Odagaon $\left(0.42 \mathrm{mg} \mathrm{kg}^{-1}\right)$

The correlation coefficient among different physico-chemical properties are presented in Table 5. Soil $\mathrm{pH}$ was significantly and negatively correlated with sand $\left(r=0.53^{*}\right)$ but positively with silt $\left(\mathrm{r}=0.65^{*}\right)$, clay $(\mathrm{r}=$ $\left.0.66^{*}\right), \mathrm{K}\left(\mathrm{r}=0.71^{*}\right)$ and $\mathrm{B}\left(\mathrm{r}=0.54^{*}\right)$. Soil organic carbon was significantly and negatively correlated with sand $\left(\mathrm{r}=0.71^{*}\right)$ but positively with silt $(\mathrm{r}=0.72 *)$ and clay $(\mathrm{r}=$ $\left.0.59^{*}\right)$. Soil available $\mathrm{N}$ was significantly and positively correlated with $\mathrm{K}\left(\mathrm{r}=0.66^{*}\right)$ and $\mathrm{S}$ $\left(\mathrm{r}=0.67^{*}\right)$. Soil available $\mathrm{P}$ was significantly and positively correlated with $\mathrm{K}\left(\mathrm{r}=0.69^{*}\right)$. Hot water soluble boron content significantly and negatively correlated with sand $\left(\mathrm{r}=0.68^{*}\right)$ but positively with silt content $\left(r=0.69^{*}\right)$ and clay $\left(r=0.76^{* *}\right)$

\section{Acknowledgement}

Authors are grateful to STCR project, OUAT, Bhubaneswar for providing financial support through research to carry out the present investigation and for providing facilities and technical support and Miss Priyanka Ray, Cartographer for preparing the maps.

\section{References}

Das, D.K. (2004) Role of geoinformatics in sustainable agriculture: Research, extension and service to the farmers.
Chairman's address. In: Proceedings of the symposium Geoinformatics Applications for Sustainable Development, 1-11, Indian Society of Agrophysics, IARI, New Delhi.

FAO. (1996). The digitized soils map of the World including derived soil properties, FAO, Rome.

Jackson, M.L. (1973) Soil Chemical Analysis. Prentice Hall of India Private Limited, New Delhi.

Kanwar, J.S. (2000) Soil and Water resources management for sustainable agriculture-imperatives from India. In: Development and Conservation. Int. Conf. Agricultural Production in 21st Century. Feb.14-18, New Delhi, pp 1737.

Mandal, D., Deeg, S.K. and Baruah, T.C. (2013) status of major nutrients in rubber soils of north-east India in relation to soil acidity. Annals of plant and soil research 15(1) : 23-26.

Mishra, A., Das, D. and Saren, S. (2013) Preparation of GPS and GIS based soil fertility maps for Khurda district, Odisha. Indian Agriculturist 57(1):1120.

Mitra, G.N., Mishra, U.K. and Sahu, S.K. (2002) Macro and micronutrient status of the soils of Orissa, IFFCO, Kolkata.

Mitra, G.N., Rout, K.K. and Sahu, S.K. (2006) Nutrient status of soils of Orissa, In: Nutrient Management of Crops in Soils of Orissa, (Editor: G.N.Mitra), pp.1944.

\section{How to cite this article:}

Tupaki Lokya, Antaryami Mishra, S. Saren and Nayak, R.K. 2019. Preparation of GPS and GIS based Soil Maps on Fertility Status and Physico-Chemical Properties of Nayagarh District, Odisha, India. Int.J.Curr.Microbiol.App.Sci. 8(11): 435-442.

doi: https://doi.org/10.20546/ijcmas.2019.811.054 